beginning of the day of the Lord. Their hearts were full of certain issues, and they were constantly looking for them ; and, when the sound of Jehovah's goings was more distinctly heard than usual, they deemed $\mathrm{He}$ was approaching to reveal Himself to the world.

4. On that day the glory of the Lord is revealed, and all flesh see it together. The earth is filled with the knowledge of the Lord. Israel has peace, and the peace descends upon the lower creation; they no more hurt nor destroy in all God's holy mountain. The external condition of the world is conceived variously. Sometimes the perfect realising of righteousness and truth seems brought down upon a condition of the world which was that of the prophet's day. The kingdoms of the nations remain. But they are no more hostile: "The nations shall come to Thy light, and kings to the brightness of Thy rising." Usually the kingdoms of the nations disappear. And external nature is transfigured; there arises a new heaven and a new earth.

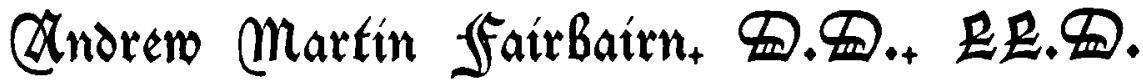

By Professor the Rer. Walter F. Adeney, M.A., London.

IN complying with the invitation of the Editor of The Expository Times to contribute a paper on Dr. Fairbairn as a theological writer, I must disclaim at the outset any pretence to that mental detachment which is sometimes desiderated as a guarantee for absolute impartiality. My high personal regard for the Principal of Mansfield College, and my admiring interest in his aims and labours, will necessarily condition what I have to say, which therefore should be read as an individual appreciation, not as a pure judgment. But while I make this frank avowal, I venture to add on the very same grounds that if, as is often asserted, the truest criticism springs from the insight of sympathy, the chance of acquiring some such insight may be pleaded as a set-off against the disadvantages of a suspected bias.

Whatever may be the opinion of various persons as to the weight and worth of Dr. Fairbairn's teachings,-and these will be sure to vary with the theological standpoint of the observer,-it is conceded on all sides that as a scholar and a thinker he can justly demand the most serious attention for the views he sets forth and the vigorous arguments with which he supports them. It is the less difficult to respond to this demand inasmuch as the reader is likely to be attracted by the literary charm of the books in which the most subtle themes are discussed with lucidity and colour. It cannot be denied that Dr. Fairbairn is that rara avis, the theologian who writes readable English. I have sometimes thought that the vigour and point of his style remind us of Bishop
Pearson, the author of the classic work on the Creed. Let any one set a page of the one writer by the side of a page of the other, and he will scarcely fail to be struck with the resemblance. More technical phraseology has crept into the language of the nineteenth century theologian in the shape of scientific and metaphysical terms which threaten to make turbid the "well of English," alas, no longer "undefiled." This was perhaps unavoidable, and to my own mind the delightful thing is that in spite of the literary misfortune it involves, Dr. Fairbairn has demonstrated the possibility of still reproducing so much of the force and clearness of the older English divines. Critics have remarked that he resorts to the use of antitheses with a frequency that savours of artifice rather than of art. It is fair to consider, on the other hand, that Dr. Fairbairn has more excuse for this device in dealing with abstract subjects than Lord Macaulay had when he stereotyped the same method in his style, although he had before him concrete facts that could be much more easily grasped. The further we advance towards ultimate principles the more antithetic all our thinking tends to become, because the expression of unmixed thought is necessarily in pronounced antagonism to its contradiction. The attractiveness of Dr. Fairbairn's style, however, is not confined to the glitter of antithesis. There is in it a singular combination of qualities not often found together. It is both picturesque and philosophic, both graphic and profound, both terse and large, both pointed and comprehensive. Iaconic in detail, it is voluminous in the mass. While the 
sentences are pruned to the utmost conciseness, the sweep of thought is exceptionally wide. The pages bristle with epigrams; at the same time they impress us with the vastness of the subjects treated.

When we turn from the consideration of language to that of method, we must be struck with a similar combination of the concrete and the abstract. Dr. Fairbairn's historical studies are among the most fascinating of his productions; and yet whenever he grapples with the great problems of being in his own speculation he leaves the variegated field of the past, and, so to speak, wrestles with them in single combat without much regard for the results attained by previous thinkers or the secular evolution of thought. The most rigorous disciple of induction must acknowledge that there is large room for the process of deduction-that Newton does not dispense with Euclid; but such a person will insist that the syllogism must follow the sifting of facts, and rest upon its products. Now it is most significant of Dr. Fairbairn's whole attitude to religious truth that he does not find the data for it in the acquisitions of previous ages of theological thought, much less does he gather it from the authoritative dicta of ecclesiastical orthodoxy. He does not study the lessons of antiquity in order to learn the teachings of the Church as a meek pupil anxiously inquiring for the instructions of his masters. He discusses ideas on their own merits, pursuing an ir priori argument in the spirit of the schoolmen rather than in that of modern historical reasoning. Thus it sometimes seems as though a great gulf were fixed between his historical researches and his theological speculations. This is very striking in a comparison of the two parts of Dr. Fairbairn's great work, Christ in Modern Theology. The first part of that book is historical and critical; the second is speculative and constructive. Each is a masterpiece, but they stand apart like the Great Bear and the Southern Cross. After tracing the history of Christian thinking with keen discernment and a firm grasp of the essential position of each successive age and its leading minds, the writer appears to turn his back on the whole of the results thereby attained, and to plunge suddenly into his own speculation as a subject attacked de noz'o, apparently regarding the elaborate historical survey as of no account, except that it has performed the educational function of cultivating the judgment and fortifying it against the errors of antiquity.
It would argue a strange blindness in the reader for him to set down this fact to some capricious eccentricity on the part of the writer. A grave reason lies behind. Dr. Fairbairn has brought out, with a great accumulation of evidence, the humiliating truth that the main current of the thinking of the ages has been anything but a normal development in the direction of a more and more correct perception of the facts of the spiritual universe. Not indeed that he is a historical pessimist. The many side thoughts that have been shot into the current from the speculations of philosophy, and from the living experience of mankind, have their own high value. Still their immediate result has been to make the stream more turbid rather than to clarify it. The book to which $I$ have just referred is the most powerful reply that has yet appeared to the root idea of Newman's Essay on Development. It has made it evident that much of the speculation of fathers and schoolmen, both Catholic and Protestant, strayed far afield, so that the most hopeful movement of our own day is not just the last step of a victorious progress, but a retrogression, a return to the first century, because a return to Christ. The historical studies of Hatch and Harnack, and the Ritschlian theology, of which the latter is a disciple, point in the same direction. The measure of our assent to this view may be determined by the degree in which it is held; but if it can be accepted in any degree-and who that knows and thinks can deny that it must?-there is a corresponding justification for Dr. Fairbairn's severance of speculation from history.

In the earliest of his works Dr. Fairbairn discusses a subject which admits of another method of treatment, and here he earnestly argues for the widespread perception of the elements of religion in the primitive thought of the race. The opposite process to following down the erratic course of Christian dogmatics, is that of tracing back the ideas of mankind to their earliest and simplest forms. This process is well illustrated in Dr. Fairbairn's Studies in the Philosophy of Religion and History. Although the book is not yet twenty years old, so rapid is the movement of mind in our own day, that it requires some effort of imagination to put oneself back in the circumstances of its origin. The science of comparative religion then presented a novel aspect to the observer. Some of its eager disciples hailed it as 
a solvent at the touch of which the superstitions of religion would vanish, and not a few timorous believers shrank from it as from the newest weapon of infidelity. It was much, then, that a scholarly and philosophic Christian writer should welcome this science and claim its products as distinctly witnessing for religion. This is just what Dr. Fairbairn did. The problcm of comparative religion has since opened out with greater complexity. But the solar theory then held the field, and most of the early traditions of religion were resolved into solar myths. In view of this situation, Dr. Fairbairn argued that the physical interpretation of the myths by no means dispelled the religious ideas which were enshrined in them. "It does not follow," he wrote, "that because they named God Heaven, they thought Heaven God." 1 Heaven might be the best expression of the conception of God. Then the solar myth itself, instead of abolishing religion by reducing its ideas to the level of a poetic description of the material facts of nature, distinctly revealed the presence of religious ideas. "If man personifies a natural object as God, he must have the idea of God." 2 Whatever, therefore, may be the explanation of the myth, the indubitable fact remains that it contains the idea of God. For religion this is its supreme significance. Moreover, it is pointed out that the early ideas concerning God are moral. God is not merely a name for the inscrutable forces of the universe. He has character. Whence do these ideas arise? Dr. Fairbairn traces them to two human faculties in contact with the observed facts of the universe and the personal experience of mankind, namely, (I) conscience and (2) imagination.

Similarly, just as the physical basis of mythology in no way removes the spiritual ideas that it contains, no mythological analogy can account for the central facts of Christianity. Here we pass from the realm of ideas to that of concrete history. Still the same principle prevails. The history of Christianity, like the underlying thought of mythology, cannot be accounted for as a mere efflorescence of poetic imagery, or as but a novel adjustment of old legends. The Incarnation of Christ is shown to be not dependent on Hebrew, Hindu, or Greek notions. It is a unique fact. So also Christianity is unique, because "the person of Christ is the perennial glory and strength of Christianity." 3

1 Studics in the Philosofhy of Retigion and History, p. 32. Ibia. p. 34 .

3 Ibid. p. 46.
Here we reach a point which I think every reader will feel to be central in the theology of Dr. Fairbairn, and the key to all his richest, ripest contributions to Christian thought. This is the intense significance accorded to the person of Christ. The treatment of this point by Dr. Fairbairn, and others who have agreed with him, has not always been rightly apprehended. It has been supposed that a claim was put forth for a new discovery of Christ on the part of the present age, and this has even been described as an interesting biographical fact in the experience of the theologian, on the assumption that having just made the discovery of the importance of Christ for himself, he had pounced on the notion that our Lord had not been appreciated by other men at an earlier date. This is a misapprehension. Dr. Fairbairn has never contended for so absurd a notion as that Christian men and women of former generations did not love and honour their Lord and Saviour. For him to have made this contention would have been to have stultified his own position. Dr. Fairbairn does not present himself as a reformer urging a return to the faith on an apostate Church. His aim is to offer a correct interpretation of the Christianity, the reality of which he, of course, admits as a continuous fact of history all through the ages. To deny the practical, vital, Christo-centric character of this historic faith would be to repudiate his own theory, which is formulated as an attempt at a more exact and true interpretation of the faith. His quarrel is with the theologians, not with the saints. The discovery of Christ, if the misleading phrase is to be adopted at all, is a discovery made within the experience of the Church, just because scholastic theology has been so involved in the meshes of metaphysics as not to be able to give the right interpretation of that experience. It is in regard to interpretation, and not in regard to experience, that we can speak of our own age as making any such discovery. I do not see how it is jossible to deny so obvious a feature of the Christian thinking of our day as the fact of its Christo-centric character. No doubt it is due to a number of influences, and among them a place must be assigned to teaching such as Dr. Fairbairn's.

'The book entitled Studies in the Life of Christ is a striking indication of the tendency of thought to which I have referred. The delicacy of perception, the depth of reflection, and the freshness in 
handling well-worn topics which are apparent throughout, render this one of the very best efforts at a portraiture of the historical Jesus of Nazareth that have appeared in a century which is noted for the number of similar attempts, many of them attaining a high order of merit. True, however, to the philosophic temper of his mind, Dr. Fairbairn does not labour to describe the traits of the external life of our Lord after the manner of Archdeacon Farrar's and Dr. Geikie's popular biographies. His aim is to discover the mind of Christ, and interpret the thought and purpose that underlie the facts narrated in the Gospels. Not to know Christ after the flesh, although our materialistic, sensation-hungering age always hankers after such knowledge, but to know $\mathrm{Him}$ as $\mathrm{He}$ is, this, according to Dr. Fairbairn, is the root-principle of Christian theology.

If we stayed here, we should be strongly urged to label Dr. Fairbairn "Ritschlian," a title which he has never welcomed, one which he would doubtless repudiate, and justly, because he cannot be appropriated by the popular German school, or any other school, for the reason that he is too independent a thinker to become the mouthpiece of any other teacher. Moreover, there are several points at which he joins issue with the Ritschlian school. The various discussions in the work entitled The City of God evince a breadth of treatment which refuses the shackles of one peculiar foreign method. Then his supremely important work, The Place of Christ in Modern Theology, shows at least two distinct points of departure from Ritschl. The first is one of substance, in the contention for the eternal living personality of Christ, revealed by the historical life in Palestine, but not confined to that life excepting in idea and influence as the Ritschlian theology virtually teaches. The other point is one of method. Though starting from history, Dr. Fairbairn soon plunges into metaphysics with all the subtlety and confidence of a mediæval schoolman-an action which would be abhorrent to Ritschl.

The great book to which I have just directed attention may be accepted as a summary of Dr. Fairbairn's ripest thought on some of the greatest questions of Christian truth. It covers between 500 and 600 pages of exquisitely concise writing, and yet so vast has the field of theology become, that, for my own part, it seems that the greatest defects of this book are due to its brevity. Several important topics are scarcely alluded to, others are treated in a manner that strikes the reader as very cursory. But innumerable volumes have been devoted to each of these topics. How, then, could they all be adequately discussed in but half of one volume? Thus this very full book is necessarily rather to be considered as an essay than as a complete treatise on theology. By some readers, too, even where the sentences run with crystalline clearness, the underlying thoughts are not so easily perceived as the lucidity of the language seems to promise; and they ask, what does Dr. Fairbairn really believe concerning this or that doctrine? I imagine that the explanation of their difficulty will be found in the fact that Dr. Fairbairn does not pretend to have abolished the mystery of theology. It is only ministering to illusion to make our definitions more exact than our knowledge.

Meanwhile the spirit and tendency of Dr. Fairbairn's theology are not at all obscure. God is interpreted through Christ, with the result that the Majesty of mere Power recedes, and the moral character of God apjears as the supreme determinant. Thus it is that "God, by the ethical necessities of His nature, becomes the Saviour." 1 Then the salvation of man is also treated ethically. Christ died for the sins of men, "and from His death two most dissimilar yet related results have followeda new consciousness of God, and a new consciousness of sin. ... The atonement has satisfied both the love and the righteousness of God,- - His love, by being a way for the recovery and salvation of man; His righteousness, by vanquishing sin within the sinner and vindicating the authority of the eternal will." 2 Thus "the ends of God in the atonement are those of the regal Paternity-the creation of an obedient and a happy universe." 3

By a curious process of reasoning, which reminds. us of patristic logic, Dr. Fairbairn finds arguments for the divine nature of our Lord in His own revelation of God. If God by His essence is love, He must be by nature social; and His very Fatherhood implies Sonship. Thus the nature of God revealed by Christ testifies to the eternal preexistence of the Son of God. To many people, no doubt, such deductive reasoning will not appear satisfactory.

The Scriptures are viewed from the same standpoint. Christ creates the Scriptures, which owe

1 Christ in Modern Theology', p. 469.

2 Ibid. p. 486. 
nothing to the Church, although they exist for the Church. "Higher criticism is higher scholarship." 1 If the canonising process were so inviolable that one could not touch its conclusions without discrediting the Scriptures, the canonising agents must needs have been infallible, so that one infallible would require many infallibilities. But history does not reveal any such infallible authorities. The process has many factors-Talmudical schools, fathers and heretics, councils and customs, local tradition and exegetical teaching. Therefore "authority belongs to the Bible, not as a book, but as a revelation; and it is a revelation, not because it has been canonised, but bccause it contains the history of the Redecmer and our redemption. ${ }^{2}$

The peculiar position which Dr. Fairbairn holds

${ }^{1}$ Christ in Modth Thoologry, p. 504. "Ithit. p. 508. at Oxford will lead many to inquire what are his views concerning the Church. For these he goes back to the first century. There then existed local $\dot{\epsilon} \kappa \kappa \lambda \eta \sigma i a$, which were essentially societies of the enfranchised or saved. If the Church had a representative it was by election. But the ideal of the local is realised in the illocal Church. This just corresponds to the new humanity, created and penetrated by Christ. A Church so conceived is as little dependent for its being on specific forms of polity as was the old humanity, for the Church as a body is not material, but spiritual, just as is its Head. To have the Spirit of Christ is to be His. "God's grace is too rich to be confined to any one channel, too boundless to be bound to councils or coteries or orders of men, infirm and fallible like all their kind." 3

3 Ibial. p. 547.

\section{Ebe Great}

\section{THE GREAT TEXTS OF II. CORINTHIANS.}

"For how many soever be the promises of God, in $\mathrm{Him}$ is the yea: wherefore also through $\mathrm{Him}$ is the Amen, unto the glory of God through us."2 Cor. i. 20 (R.V.).

\section{ExPOSITION.}

"The yea... and the Amcn" (Tò rai and rò $\left.\dot{a} \mu \eta^{\prime} \nu\right)$ cannot be synonymous. This is rendered impossible by the correct reading, "wherefore also

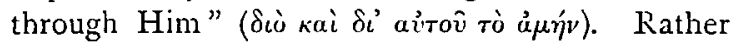
must the former be the cause ( $\delta$ ió) of the latter. And here the expression "the Amen" is without doubt to be explained from the custom in worship, that in public prayer a general Amen was said as certifying the general assurance of faith as to its being heard. Accordingly "the yea" and "the Amen" are to be distinguished in this way: "The yea" denotes the certainty objectively given, and "the Amen" the certainty subjectively existing, the certainty of faith. Consequently, For, as many fromises of God as there are (in the Old Testament), in Him is the yea (i.e. in Christ is given the objective guarantee of their fulfilment); therefore through Him also the Amen takes place (i.e. therefore also to Christ, to His work and merit, is due the subjective certainty of the divine promises, the faith in their fulfilment).-MEver.

"Through us," by our ministry, in so far, namely, as the ministry of the gospel-preachers brings about the Amen, the assurance of faith in God's promises. -MeYer.

Since in Christ God reasserts the old promises, also through Christ men believe them, and shout Amen.-BeEt.

"To the glory of God."-Glory redounded to God through St. Paul and his colleagues, because they preached, and their hearers accepted thankfully, a Christ who left none of God's promises unredeemed, but made Him a true God who keepeth covenant.-IVAITE.

\section{Methods of Treatment.}

I.

GOD'S CERTAINTIES AND M.AN'S CERTITUDES.

By' the Rio, Alexander Maclarn, D.D.

This is one of the many passages the force and beauty of which are, for the first time, brought within the reach of an English reader by the alterations in the Revised Version. In the Old 